\title{
ETNICITÁS, IDŐSTRUKTÚRÁK A VOLT JUGOSZLÁVIA GEOPOLITIKAI RENDSZERÉBEN ${ }^{1}$
}

\author{
(Etnicity, Time Structures in Geopolitical System of Former \\ Yugoslavia)
}

\section{MEZÖ FERENC}

A liberális demokrácia győzelme és a kapitalista piac hegemóniája a világ sok részén együtt járt a nacionalista érzelmek erösödésével, különösen azokkal, melyek mostanában „szabadultak” fel a „múködő szocializmus” totalitárius rendszerei alól. A nacionalizmus sok kommentátor szerint csak egy viszonylag új társadalmi és kulturális jelenség - ideértve Fukuyamát is (1994), aki „,különösen modern jelenség"-ként írja le, mert a nacionalizmus visszahelyezi a birtokos-jobbágy viszonyt a kölcsönösség és az egyenlöség elismerésének helyére. Demokratikusabb és jogosabb - mondja - egy örökletes monarchiánál, de nem „,teljesen ésszerü", mert mind benne foglalva, mind kizárva (kimondva-kimondatlanul), csak néhány embert ismer el a kiváltságos csoport tagjaként, szemben minden emberrel, amely Fukuyamának az individuális értékekről, mint a történelemnélküli társadalom talppontjáról alkotott elméletének alapja.

Miért fontos kortárs jelenség a nacionalizmus, miért választott identitás kifejezési forma manapság a világ számos részén? A jelenlegi összefüggésben a nacionalizmus és territorialitás közötti kapcsolat különösen érdekes, és ennélfogva a kulturális szempontokon alapuló nemzetállamok kialakulása is. Sehol sem tisztább ez jelenleg, mint a széttöredezett Jugoszláviában, ahol a szövetségi állam etnikai vonalak mentén történt felbomlása, és hasonlóképp egyik alkotórészének (Bosznia-Hercegovina) belső szerkezete áll a Tito utáni politikai térkép kialakulásának középpontjában. Mi mást láthatunk e háborúkban, mint új területi egységek létrejöttét, amelyeknek kikényszerített léte a territorialitás paradigmájának példája. Az „etnikai tisztogatás” magában foglalja a tér használatát a hatalom gyakorlására a nemkívánatos csoportoknak némely területekről való eltávolítása által, és korlátozásukat mások által: ez ismét teljes apartheid, még hatalmasabb gyülölettel, és az ember semmibevételével.

Ez egyáltalán nem újdonság a világnak ezen a részén. Wilkinson (1951) egy mellózött müvében rámutatott, hogy a határok meghúzása Macedóniában az I. világháború után miként hagyta figyelmen kívül az etnikai határokat, igazából éppúgy, mint az Észak-Írország és az Ír Köztársaság közötti határrendezés. A kulturális csoportok által használt területek a territoriális egységek világát alakítják ki. Ezekben nem képesek szabályozni és elhárítani a globális kapitalizmus erőit, ám képesek

- és ez sokak számára lényegesen fontosabb - oly módon megszervezni társadalmi és kulturális életüket, hogy az individuális érték (amit Fukuyama a történelemnélküli társadalom fö vonásának tart) teljes mértékben tagadottá válik. Fukuyama érdekes módon úgy érvel, hogy a liberalizmus végső fokon megszabadít minket a 
nacionalizmus béklyójától éppúgy, miként a vallás bilincseitől (1994), ahol a nacionalizmus képes meggyengülni és modernizálódni látszik - hasonlóan a valláshoz -, ahol az individuális nacionalizmusok elfogadnak egy elkülönült, de egyenlö státuszt, az imperializmus és a háború nacionalista alapja jelentősen meggyengül.

A nacionalizmus elenyészése magával hozza az interetnikus tolerancia növekedését, az identitások elkülönúlésével, de egyenlö félként való szövetségével. Hiszi, hogy miként a vallást -, a nacionalizmust sem fenyegeti az eltünés veszélye, de - mint a vallás -, úgy tünik, sokat veszített azon képességéböl, hogy az európaiakat arra ösztönözze, hogy kockáztassák kényelmes életüket az imperializmus érdekében.

Ez ellen szól jellemzése a szóban forgó jugoszláviai és más nacionalizmusokról, melyek intoleránsak, soviniszták és megjelenésükben agresszivek. Ezek Európa legkevésbé modernizált részén lelhetőek fel, nem tünik valószínünek, hogy a fejlett országok befogadják őket, és sok esetben ,átmenetet képeznek” egy új demokratikus rend felé haladásban. Végső soron - következtet - a liberális demokrácia államai a kapitalista piacok hegemóniájával gyözedelmeskednek rajtuk és minden csodás lesz!

Manapság közhelynek számít azt állitani, hogy egy régi, haldokló és egy születendő új világrend közötti átmenetben élünk. Különbözó elméletek sokasága próbálta már körvonalazni ezt az átmenetet. Néhány szerint egy torzult, de még izgalmas átmenetet élünk meg egy ún. Második Hullámú Kultúra, amelyben az ipari társadalom normái érvényesülnek és egy szabad kapitalista Harmadik Típusú Kultúra között, amely egy teljesen új norma-, érték- és viselkedésrendet hoz majd létre. Más elméletek szerint elértük a történelem végét, és az elöttünk álló „szinmü” nem más, mint egy, az egész bolygón győzedelmeskedó liberalizmus.

Megint mások az eljövendő világrend sötétségét (árnyoldalait), ellentmondásait és korlátait hangsúlyozzák, aláhúzva, hogy egy teljesen neoliberális világrend gyözelme lehetetlen egy anarchikus és mindent átfogó decentralizált, többnyelvú világában. Természetesen a Szovjetunió 1991-es összeomlása kizárólag úgy értelmezhetö, mint egy korszakalkotó esemény. A történész Eric Hobsbawm ezt a dátumot használja az ún. „rövid XX. század” végének megjelölésére. Szarajevóban kezdődött 1914-ben, és eléggé ironikus módon nemcsak a szovjet birodalom összeomlásával zárul, hanem (ott, ahol elkezdödött) a nacionalizmus eröi által ostromolt Szarajevóval (Hobsbawm 1998).

Korábban e században láthattuk, hogy a nemzetállam képviselte a politikai fôldrajz ${ }^{2}$ fejlódésének csúcsát. Valójában a nemzetállam fogalmát szívesebben használjuk úgy, mint az állam szó szinonimáját. Viszont a nemzetállamok távolról sem egyetemesek a modern világban. 1978-ban Conner kifejtette írásában, hogy általában véve 132, a valóságban létezó államot figyelt meg 1971-ben, ezek közül csak 9,1-12\% volt valójában olyan állam, amely határai megegyeztek vagy közel megegyeztek egyetlen nemzeti csoport eloszlásával. További 25 esetben egyetlen nemzet tagjai az összlakosság több mint $90 \%$-át tették ki, de ezek szintén magukba foglaltak egy fontos kisebbséget, amíg másik 25 esetben egy nemzeti csoport elérte a népesség 75-89\%-át, de 39 esetben a legnagyobb nemzet vagy lehetséges nemzet potenciálisan kevesebb, mint a népesség felével számolt. Később, 1993-ban a 
180 mai államból nem többet, mint 15-öt tudott nemzetállamnak minősíteni: Japánt, Izlandot, a két Koreát, Portugáliát és néhány mást. A soknemzetiségủ állam így könnyedén az ország leggyakoribb formája, statisztikailag és/vagy politikailag legalább két kiemelkedő csoportot tartalmaz. Az összes állam 40\%-ában van öt vagy több ilyen csoport. Talán a legmeglepöbb statisztikai adat az, hogy az összes állam közel harmadában (31\%) a legnagyobb nemzeti csoport még csak nem is a többség (Conner 1993).

$\mathrm{Az}$ úgynevezett „nemzet-állam” rendszerkülönbözöségének és változékonyságának tarkaságát, mint további figyelmeztetést írja le Falk (1992), mely eszünkbe juttatja Eric Erikson (1975) szavait: a XXI. évszázad újra a nacionalizmus időszaka lehet, és éppen ezért a nemzetet és az államot összemosni, nemzetállamot ideális viszonyként, struktúraként - melyre törekedni egészséges folyamat - feltüntetni, igen veszélyes lehet:

1990-re több mint 800 nacionalista mozgalom volt a világon, de kevesebb, mint 200 állam. A 800 ,igénylő” között sok kicsi, gyenge, szétszórt, életképtelen, de nem szükségszerủen a sorsába beletörődött nemzet volt. Nincs lehetőség arra, hogy mindezeket a nacionalista igényeket ki lehetne elégíteni államiság létrehozásának engedélyezésével. Tulajdonképpen területi követelést gyakran úgy fogalmaznak meg, hogy az egyik nemzeti sors követelése kizárná a másikat ${ }^{3}$.

A „nemzetállam” az állam és nemzet területi és politikai egyesitéséből származott. A nemzetek bonyolultságait és ellentmondásait már áttekintettük, de az állam még mindig vizsgálatra szorul. Oppenheimer (1912) biztosított az államnak egy tömör definíciót, amelyik még mindig megfelelöbb, mint bármelyik más megállapítás, amikor azt írta: egy állam akkor kezd élni, amikor egy nép letelepszik egy területen saját szuverén kormányzása alatt. Az általa megadott négy jellemző közül az egyik, amelyik az államot úgy különbözteti meg a szervezett terület más egységeitöl, mint törzsi területektől vagy közigazgatási megyéktöl, az maga a szuverenitás. Lehetne vitatkozni arról, hogy vajon a szuverenitás átruházódik-e a törvényes kormányzatra, az alkotmányra, az emberekre vagy a monarchiára ${ }^{4}$, de a szuverenitás lényege annak elutasításában rejlik, hogy más, felettes hatalom létezését elfogadja. Ekképpen a szuverenitás a legfontosabb hatalom, amelyik nem ismer el felettest, és amelyiken túl nincs törvényes hatalom (Frankel 1964, 13). Ennek következtében az államok igénylik, hogy kisajátítsák maguknak a törvényes hatalmat adott teruleten belül, és az utolsó fél évezred történelmének nagy részét úgy lehet megfogalmazni, mint az energia és erőszak mennyisége, amire azért van szükség, hogy biztosítsák a monopolista államkövetelések betartását. A mindennapi életben akár a nemzetre, zászlóra vagy a nemzeti érdekekre való hivatkozással az államok óriási erőforrásokat mozgósítanak, hogy biztosítsák ennek a monopóliumnak a fenntartását.

A szuverenitás védelme alatt az állam úgy létezik, mint folyamatos kapcsolat vagy diskurzus emberek, kormány és terület között. Mann megjegyzi: az állam területi szervezet, amelyik létrehozza hatalmának megkülönböztető formáját. Ellentétben más hatalmi csoportositással a polgári társadalmon belül, az állam központosul egy lehatárolt terület körül, amely felett hatalmat gyakorol, vagy megpróbál 
hatalmat gyakorolni (Mann 1984). Ezért fekszik a területiség kérdése az államelmélet középpontjában. Az állami szuverenitás arra készteti az embereket, hogy szétrepesszék a szuverén terülęteket és ne az emberiségre, mint egészre gondoljanak. Ez nem egyirányú folyamat, ezzel párhuzamosan egységesülési folyamat indul be, amely egybefonja a kultúrákat, nemzeti csoportokat az adott állam határain belül. Az állam olyan mércéket állít fel, mely a határokon kívül élö csoportokkal megakadályozza a rendszeres párbeszédet és kapcsolatrendszert. Ez bizonyítja, hogy vannak emberek, akik a világot befogadás és kizárás, vagyis "mi” és „ôk" kapcsolatban, ilyen módon kifejezett fogalmakban képzelik el. Ha a világ befogadás és kizárás, valamint közösség és anarchia, civilizáció és barbarizmus közötti éles felosztások sorozata alapján van megszerkesztve, akkor a háborús elökészületek nyújtják az egyetlen garanciát ahhoz, hogy a béke tartós legyen (Walker 1990).

Megfigyelhetjük a térbeli egybevágóság általános hiányát az állam és nemzet között, így amíg a szuverén állam rendelkezik népességgel, addig a népesség valószínü, hogy kulturálisan tłljesen különbözö. Ezzel ellentétben a nemzet egy olyan népböl áll, amelyet kưlởnbözö kulturális, politikai és történelmi sajátosság egyesít úgy, mint a közös nyelv vagy vallás, de legfontosabbak a megosztott közös tapasztalat tényezői, a közös vágyódás és a fizikai, talán helyesebben érzelmi kötelék egy bizonyos területhez ${ }^{5}$. A nemzetiesség és területiség tényezöi különféle módokon kapcsolódtak össze. A zsidók például fizikailag szétszórtak, részlegesen felosztódnak a nyelv által, csekély jelentőségben felosztottak a vallás által, de összekapcsolódtak a visszaszerzendö cél, Izrael folytán, egy pontosan behatárolt terület visszaszerzésének mindennapos törekvése által. Az angolok és franciák kitöltötték előbb létezó államokkal a területi burkot úgy, hogy államaikat később keltezték, amíg bizonyos nemzeteknek, mint a határmenti kurdoknak Törökország, Irán és Irak között, vagy a spanyolországi baszkoknak a nemzetállam még mindig törekvés. Minden egyes nemzeti csoportnak van egyfajta sajátságos érintkezése a területtel.

Egy nemzet és a nemzeti terület között különféle méretü (dimenziójú) lehet a kötelék. Néhány esetben a terület elfoglalása lehet, hogy nem több, mint népi emlékezet olyan módon, mint a vágyódás Izrael visszaszerzésére, ami több évszázadra egyesítette a zsidókat. Lehetnek olyan esetek, ahol a területi szempont nem a nemzeti identitásnak az összetevóje. De vannak más olyan esetek, ahol a terület és egyéb körülmények irányították a nemzetek kialakulását, mint több délszláv nemzet esetében, akik ennek a legkiterjedtebb alanyai. Nos, nézzünk vissza a történelem előtti időbe! A nép, amely egy ösi szláv nyelvet beszélt, Észak-Ukrajna és Belorusszia vidékein bukkant fel. Késöbb a szláv vándorlás különböző irányban szétrajzó hullámai során elfoglalták helyưket. Egy nagyobb csoportot alkottak a nyugatiszlávok, akik a lengyeleknek, cseheknek és szlovákoknak az ösei. Más ösi szlávok ott maradtak, ahol voltak, egyesek észak vagy kelet felé mozdultak, és a keleti szlávok előfutáraivá váltak. Ök beloruszokra, ukránokra és nagy-oroszokra váltak szét. Mások még mindig sodródtak dél felé a Balkánra, és délszlávokká lettek.

Ezekben az időkben valószínü, hogy a délszlávok kulturálisan egy népet alkottak. De amint szétszóródtak az erősen feldarabolódott hegyes-völgyes terepen, és kủlön- 
állókká váltak, különbségek kezdtek kialakulni. A terep hozzájárult az ellentétek kialakulásához, de egyéb helyzeti tényezök szintén döntő szerepet játszottak, mivel különböző csoportok tartoztak különböző idegen uralkodóházak irányítása alá. Északon a szlovének a Római Katolikus Egyházhoz tartoztak, és területeiket hozzácsatolták Ausztriához. Távolabb, délen, a horvát földek a magyarok ellenơrzése alá kerulltek. A horvátok átvették az egyházi irányítást Rómától, és a Habsburg Birodalom kebelezte be akárcsak Magyarországot. De távolabb, dél és kelet felé a szerbek Bizánc hatására tértek át a kereszténységre. Következésképpen éppúgy elfogadták az ortodox hitet, mint ahogy elfogadták a cirill irást is. Közel ezer évvel ezelőtt a szlovén nyelv, amit úgy irtak le, mint a legszebb szláv nyelvet, kezdett elágazni más délszláv anyanyelvektöl. Az 1389-es rigómezei csata ${ }^{6}$ után a szerb területek török ellenörzés alá kerültek, és török uralom alatt maradtak a XIX. századig. Ennek következtében gazdasági tényezők járultak a földrajzi, politikai és kulturális tényezőkhöz, amelyek fokozatosan feltagolták a délszláv népeket. A törökök szigorú, kizsákmányoló fennhatóságot gyakoroltak, és területeik kevés ipari, mezögazdasági és oktatási fejlődéssel jellemezhetőek, nem úgy, mint azok a területek, amelyek osztrák és magyar ellenörzés alatt voltak. Időközben a szerbek kulturálisan megoszlottak. Az ortodox nemzet janicsár katonák által vezetett muzulmán uralkodó rétegnek volt alárendelve, akiket jórészt az olyan ortodox keresztény fiúk közül toboroztak, akiket már elvettek a szüleiktöl, áttérítették öket muzulmán hitre, és alávetették öket egy alapos katonai kiképzésnek. Jelentős számú ortodox szerbnek sikerült megmenekülnie a török kizsákmányolástól azáltal, hogy elvándorolt északra, vagy a hegyek közé költözött. Általában az egyház szervezte meg a titkos elvándorlást. Más szerbek maradtak, sokan előnyösnek találták, hogy áttérjenek a hódítók hitére. Ezen a módon egy viszonylag jelentős muzulmán alkotórész fejlődőtt ki Bosznia szerb népességén belül.

A délszláv népek különbözó alkotórészei kủlönböző időben nyerték el függetlenségüket, gyakran a felszabadulás átélésének élménye inkább volt megosztó, mint egyesítő tényezö. A török uralom elleni szerb felkelés 1804-ben igen komolyan elkezdődött, de a teljes függetlenséget nem nyerték el 1878-ig. A szerb nacionalizmus a korábbi orosz érdekeltségnek használhatott eszközeként, mind a szerb, mind a cári politikusok a pánszlávizmust használták ki - másképpen az idealisztikus mozgalom hitét - a darabokra tört és kihasznált szláv emberek újraegyesitéséhez.

Még most is nagyon nehéz megérteni az I. világháború okát. Tudjuk, hogy az első pisztolylövés akkor dördült el, amikor Ferenc Ferdinánd osztrák föherceget meggyilkolták Szarajevóban. Az Osztrák-Magyar Monarchia ekkor hadat üzent Szerbiának, ez Oroszországot mozgósította szerb oldalon, Németország kőzbelépett Ausztria-Magyarország, Franciaország pedig Oroszország megsegítésére. Az 1914-18-as háború eseményei még inkább hozzájárultak a délszláv nemzetek közötti szakadék mélyüléséhez.

Szerbia és Montenegró harcolt az Osztrák-Magyar Monarchia ellen, míg a horvátok és a szlovének az OMM-hadseregét erösitették. A szerbek iszonyúan szen- 
vedtek ebben a háborúban, a lakosság harmadát majdnem megölték a csatamezökön, vagy a borzalmas ütközetek következményeiben pusztult el.

A Központi Hatalmak veresége után Nagy-Britannia és Franciaország megbüntette ellenségeit úgy, hogy legyengítette azokat az államokat, amelyekkel újabb háború robbanhatna ki. Az Egyesült Államok több idealista álláspontot fogadott el, melyet a nemzeti önállóság politikájával támasztott alá (ebben jelentỏs szerepe volt Isaiah Bowmannak').

Tökéletes alkalom volt hasonló elvet végrehajtani a gyakorlatban: A cári Oroszország a forradalom fájdalmában gyötrődött, míg az Osztrák-Magyar Monarchia, a Török és a Porosz Birodalom vereséget szenvedett. Európa térképét átrajzolhatták olyan módon, hogy szabadjára ereszthették Európa alárendelt nemzeteinek felgyülemlett vágyait és sérelmeit. A győztesek így folytathatták elképzeléseik megvalósításait a szuverén államok csoportjairól, ugyanakkor ütközöállamok sorát hozták létre Németország és Oroszország között (puffer zóna).

A szlovének, horvătok és szerbek képviselői több megoldást elfogadtak, amelyet a szövetségesek elöirtak a korfui találkozóra a háború vége elött, és beleegyeztek abba, hogy egy egyesített délszláv államot alakítanak ki a Központi Hatalmak végsö veresége után.

Amíg csak egy indokolt kívánság volt, hogy megalkossák a délszláv egységet, addig a küldöttek ijedtek is voltak, hiszen Olaszország elörenyomulhatott az Adriaitenger mentén, a Balkán irányában területeket foglalhatott el az Osztrák-Magyar Monarchia és a Török Birodalom roncsától. Azonban az idö és a távolság már különbségeket teremtett a délszláv népek között. A szerbek politikai vezetésröl és lelkesedésröl gondoskodtak, de a szlovének és horvátok szemében - akik római katolikus kultúrában éltek az Osztrák-Magyar Monarchia alatt -, a szerbek ,fejletlen" nép maradt. Attól is féltek, hogy a délszláv állam egy Nagy-Szerbia létezését eredményesen bizonyíthatja a nem szerb kisebbségek hátrányára. Időközben a szerbek megosztották magukat az ortodox keresztény és a muszlin vallás között. A különbözö nemzetek különböző célokkal és reményekkel léptek be az új államba. A szerb uralkodó elit sok tagjának Jugoszlávia jutalom volt a háború miatt a nemzet által elszenvedett áldozatokért és fájdalomért, de a horvát és szlovén vezetés nagy részének Jugoszlávia csak egy lépcső volt a nemzeti függetlenség felé való haladásban. Idöközben a fejlettebb nemzetek úgy tekintettek rá, mint egy ellenséges hatalomra (Licht 1993).

Jugoszlávia úgy született meg 1918 novemberében, hogy az élet egy központosított monarchiában, a Szerb Királyság alatt kezdődött. Ebben az idöben egy határok nélküli állam volt, amely tárgyalások által darabonként nöttön nőtt. Ez alatt a határgyártási folyamat alatt Jugoszlávia szert tett különböző nem szláv kisebbségekre, amelyek rendkívüli méretü feszültséget teremtettek lehetséges individualizmusukkal, vagy a Jugoszlávián kívül élő hasonló nemzetiségủek betörése által. Az új határvonallal Magyarország magyar és német népességet tartalmazó területeket „adott” Jugoszláviának. A déli határvidék sok muszlin albánt foglalt magába, míg szláv többségủ területet vesztettek el Olaszországnál, az Adriai-tenger mentén. 
Ráadásul kezdettől fogva látható volt az összetartozás hiánya a délszláv nemzetek között. Amikor egy népszavazást szervezett a Szövetségesek Bizottsága Klagenfurt város környékén, a népszavảzás zavaró eredménye megmutatta, hogy a szlovének elönyben részesítették az ausztriai tagság megörzését, így a népszavazást feladták.

$\mathrm{Az}$ új államban a szerbek számbeli fölényben és politikailag uralkodó helyzetben voltak. A keresztény délszláv népesség kb. 6 millió szerbböl, 2,6 millió horvátból, 1,I millió szlovénből és fél millió macedón szlávból állt. Azon kívül Jugoszláviához tartozott kb. 600 ezer muszlin szerb és különböző nem szláv népesség, plusz 450 ezer magyar, 400 ezer német, 250 ezer albán, 150 ezer román és kb. 175 ezer más nemzetiségü ember.

A háborúk közötti időszakban Jugoszlávia létrehozásának oka föként az a délszláv félelem volt, hogy Olaszország, Bulgária, Magyarország vagy Németország megtámadja öket, valamint az a gyanakvás, hogy szövetség jöhet létre Olaszország és Albánia között azért, hogy elvágják Jugoszláviát tengeri útvonalaitól. A szerbek uraiták az új állam hadseregét és a közigazgatást, igazolva ezzel a horvátok és szlovének félelmét a szerbek hatalomra jutására vonatkozóan, míg az ország hegyek által történö felosztása megnehezítette a gazdasági és szállítási rendszer integrálását. Amikor a harmincas években a náci Németország inváziójának fenyegetése erösödött, kísérlet történt egy nagyobb hatalommal felruházott kormány felállítására abban a reményben, hogy az enyhíteni fogja a belsỏ feszültséget és elösegíti az egyesülést. Szővetségi alkotmányt fogadtak el, Horvátország önkormányzati jogot kapott.

Az 1941 -es német inváziót követỏen Jugoszláviát feldarabolták úgy, hogy Szlovéniát felosztották Németország és Olaszország között. Montenegrót (Vuksanovičrendszer), Koszovót és Macedónia nyugati területeit szintén olasz ellenőrzés alá helyezték. Bácskát, Dél-Baranyát és Muraközt Magyarországhoz csatolták (összesen $11,475 \mathrm{~km}^{2}$ ). Horvátországban létrehoztak egy fasiszta párthú államot (Pavelicrendszer), $\mathrm{s}$ az bekebelezte Boszniát, Macedónia nagy részét pedig megkapta Bulgária, míg Szerbia úgy múködött, mint egy megszállt bábállam (Nedič-rendszer). A megszállás során a legszörnyủbb atrocitásokat követték el a horvát fasiszták a szerb nacionalisták ellen, és fordítva, növelve az etnikai gyűlölet örökségét. Nyugati becslések szerint azoknak a szerbeknek a száma, akiket az úgynevezett Független Horvát Állam usztasái (ustaša=felkelés) megöltek, 600 ezer és 1 millió közőtt mozog.

Ennek ellenére csak Jugoszlávia és Albánia volt az az ország, amely a Szövetségesek különösebb segítsége nélkül felszabadította magát a náci uralom alól, bár azt a küzdelmet, melynek során német, olasz, boigár és magyar megszállás alól szabadítottak fel területeket, polgárháború követte, mely egymás ellen uszított jugoszláv nemzetiségeket, politikai ideológiákat egy sokoldalú versengésben. A délszlávok egysége Tito kommunista partizán vezér támogatásával valósult meg, akinek seregei bátran és eredményesen harcoltak a megszállók ellen, és aki fölényes választási gyözelmet aratott az újjáalkotott Jugoszláviában. Tito életében személyes vonzereje, határozott vezetése - összefonódva a külső eröktől való félelemmel - tartotta össze Jugoszláviát. 1946-ban új szövetségi alkotmányt fogadtak el, amely az országot fel- 
osztotta Bosznia és Hercegovina, Horvátország, Macedónia, Montenegró, Szerbia és Szlovénia köztársaságokra, és létrehozta Vajdaság és Koszovó autonóm tartományokat Szerbiában, valamint elismerte a mohamedánok kưiőnnálló nemzeti státuszát, miközben 1948-ban Tito elutasította a moszkvai irányvonal követését, így Jugoszláviát kizárták a kommunista blokkból. Az 1950-es és 1960-as években a gazdasági növekedés és az emelkedő jólét segített elterelni a figyelmet a belső felosztásról, amit még megerősítettek a kisebbségeknek nyújtott szövetségi koncessziók, valamint az a szükséglet, hogy fenntartsanak egy kényes politikai egyensúlyt a keleti és nyugati hatalmak között. Mindamellett az államapparátus minden próbálkozást elnyomott, ami az etnikai különbségek nyilvánosságra hozatalára irányult, így a jugoszláv egységet inkább felülröl eróltették, mintsem az a közösség gyökereitől eredt volna. Időközben a szővetséges politikai struktúrák oly módon támogatták a médiát, hogy abban a titkos nacionalista politikusok épithették karrierjüket, különösen az 1970-ben bevezetett decentralizációs politika segítségével.

Ennek ellenére sok megfigyelő számára világos volt, hogy a délszláv egység nem sokáig éli túl Tito halálát. A Balkánon - amely már régóta a nacionalizmus geopolitikai melegágya volt - Jugoszláviának, mint soknemzetiségủ államnak a létezése abnormálisnak tekinthetỏ. Tito meghalt 1980 májusában, így fokozatosan azok a centrifugális erők, amelyek az országban szunnyadtak, elkezdtek felerösődni. A politikai különbségek ellenére mégis elöfordulhatott, hogy a szerb és horvát nyelv közel hasonló maradt, a szerbhorvát anyanyelvủek az egykori államszövetség szerb, horvát, muszlin és crna gorác lakosai, vagyis az 1991 -es népesség $71,2 \%$-a, azaz 16,8 millió fo. ${ }^{8}$ Természetesen az utódállamok mindegyike hangsúlyozza, hogy létezik külön szerb, horvát, sőt bosnyák nyelv, illetve Montenegróban is a szerbtöl némileg eltérő nyelvjárást beszélnek (Romsics 1998). Ennek ellenére ezen nyelvek alig kulönböznek egymástól (inkább csak egyazon nyelv dialektusainak tekinthetők), habár világosan látszik a szándék arra, hogy e tizenhétmilliós nyelvi kőzösségből külön-külön nyelvi közösségeket teremtsenek. Erre meg is van a valós lehetöség, amire elég bizonyiték lehet a bolgártól alig különböző macedón nyelv adminisztratív úton történt kialakítása 1945 után. ${ }^{9}$ A nyelvi diverzitás az idö múltával pedig nöni fog. ${ }^{10}$

A vallási tagoltság nagyobb a nyelvinél, emellett szerepe is jelentósebb a nemzeti önazonosság meghatározásában (I. ábra).

A legnagyobb vallási közösség - amely alatt nem a hívők száma és aránya értendö, hanem a kulturális hovatartozás - a görögkeleti (ortodox, pravoszláv) keresztényeké: lényegében a szerbek, macedónok és montenegróiak tartoznak ide, összesen mintegy 10,6 millióan, akik a lakosság 45\%-át tették ki az egykori Jugoszláviában.

A római katolikus horvátok, szlovének és magyarok 6,8 millió fövel (29\%) a második, a muzulmán vallású bosnyákok ${ }^{11}$ (muszlinok) és albánok kb. 4,5 millióval (19\%) a harmadik legnagyobb vallási közösséget képviselik. ${ }^{2}$ A szerbek kimutatták dühưket, szerintük túl nagylelkü engedményeket tettek a nem szerb kisebbségeknek, ezzel egy szerb hegemónia esélyét veszélyeztetve. 


\section{1. ÁBRA}

A civilizációk részesedése a második Jugoszlávia és utódállamainak lakosságából (The Population of Second Yugoslavia and It's Successor State by Civilisation)

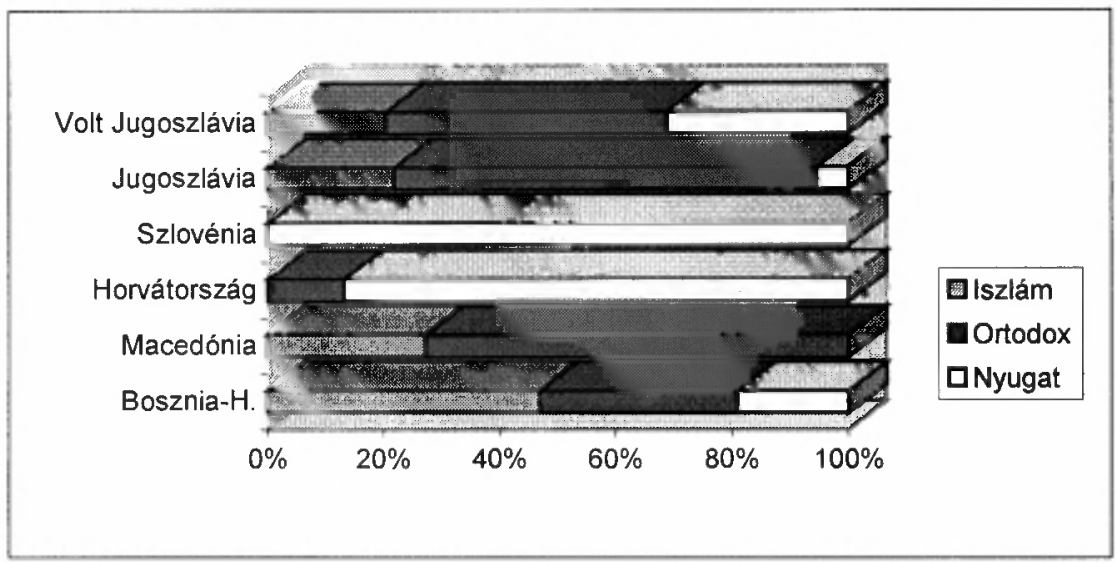

Forrás: Huntington 1998.

1988. november 1-jén 1 millió szerb tüntetett Belgrádban, egy gondosan megrendezett kampányban a koszovói szerb közősségek elleni állítólagos támadások ellen, amit albánok követtek el. Bár a térségben nagyszámú albản lakosság él, mégis a szerb kultúra bölcsőjének tartják. ${ }^{13}$ A szerb harag bizonyos fokig reagálás volt a gazdasági nehézségekre, amely sztrájkokban, a fizetések befagyasztásában, valamint 200\%-os inflációs rátában tükröződött. Ezzel egyidőben feltủnt egy „rókaarcú”, szélsőségesen nacionalista politikus, Szlobodan Milosevics. Sajnálatos módon ezt a prototípust követték többen a szerbek körében és más nációkban is. E politikusokat jelentős felelősség terheli a konfliktusok kirobbanásában és azok elhúzódásában.

Az 1991-es év közepére kitört a polgárháború, függetlenséget követelve Horvátországnak és Szlovéniának. Ebben a két tartományban sokkal magasabb volt az életszínvonal, mint ami tapasztalható volt a másik két köztársaságban. A horvátok és szlovének Jugoszlávia lakosságának csak 20 , illetve $8 \%$-át alkották, akik megbízhatatlanok kezdtek lenni a lakosság 36\%-át kitevő, és a hadsereget uraló szerbek szemében. Szlovénia aránylag könnyen vívta ki függetlenségét, Horvátország egy véres háború révén, de a legkegyetlenebb harc a szerbek, muzulmánok és horvátok között az etnikailag sokrétü Bosznia államban folyt. Ez a harc új fejezeteket nyitott a nemzeti gyúlölet mitológiájában. Az elfoglalt területek visszataszitó „etnikai tisztogatása" a náci időkre emlékeztet.

1995 novemberében szerb, horvát és muzulmán képviselők szerződést írtak alá Daytonban $^{14}$, az Egyesült Államok Ohio államában. A Dayton-i egyezmény szerint Boszniát ténylegesen két mini államra osztották, a Boszniai Szerb Köztársaságra és a muzulmán-horvát szövetségre. A szerb területet Bosznia gyakorlatilag kettévágná oly módon, hogy a Posavina folyosó lenne a kapcsolat az ország két legészakibb része között. Szerb győzelmek és terjeszkedések hosszú sorozata után az egyezményt csak a horvát és muzulmán gyors elörehaladást követỏen sikerült megkötni. 
Az egyetlen csoport, aki hasznot húzott az egyezményböl, az horvát volt. A horvátok tekintélyes hadállásokat és tárgyalási jogot nyertek, míg a szarajevói és palei szerbek, valamint a kelet-boszniai és banja-lukai muzulmánok területet vesztettek. A háború következményeként Bosznia népességének fele menekült lett, valamint $\mathrm{kb} .200$ ezer embert öltek meg. Amikor a horvát hadseregek visszavonultak a Dayton-i egyezmény alapján átadott terủletekröl, felgyújtották az általuk elhagyott falvakat.

Azok a problémák, amelyek az új „törzsi rendszer” eltörlésével asszociálódtak, azok Jugoszláviában is léteztek, és annyira földrajzi vonatkozásúak, mint politikaiak. Földrajziak voltak a terület és a relatív elhelyezkedés tekintetében, amely a délszláv népek szétszóródását eredményezte a Balkánon, és abban a tekintetben, hogy ezek a szórványok ki voltak téve különbözỏ kultúraformáló hatásoknak. Amikor elkezdödött a harc az 1990-es években az etnikailag vegyes összetételü szövetségi csapatok között, a fôldrajz is fontos szerepet játszott. Szlovénia, ahol a függetlenséget 1991ben kiáltották ki, aránylag könnyen jutott autonómiához, részben azért, mert nem volt nagy számban szerb kisebbsége, ugyanis a szlovének alkották a kétmilliós lakosság 91\%-át.

Horvátországban, ahol ugyanakkor kiáltották ki a függetlenséget, a harc ádáz volt és hosszan tartott, mert a lakosság 12\%-a szerb volt, és az elöző köztársaság területének 30\%-a a bennszülött szerb szeparatista lakosság irányítása alatt állt. 1995-ben egy nagyobb horvát offenzíva visszaszerezte Krajinát, az ország délkeleti részén fekvő terủletet, miután kilakoltatta a szerb lakosságot (a szerbek aránya 3\%-ra csökkent). De Bosznia volt az az ország, ahol mind a tömegmészárlás (nagyobb része hidegvérrel és kiszámítottan), mind az etnikai elemek megtizedelése a legnagyobb volt. Itt a szerbek, muzulmánok és néha a horvátok küzdőttek, nemcsak azért, hogy növeljék megszerzett terulleteiket, hanem azért is, hogy háború vagy tárgyalás útján szerezzenek olyan földrajzilag egységes foldterületet, amely alkalmas egy életképes állam megalapításához. Így a boszniai szerbek elörenyomultak Dubrovnik horvát kikötő felé, megkísérelve a tengerhez való kijutást, mikőzben azon is fáradoztak, hogy fenntartsanak minden közúti összeköttetést a szerb anyaországgal (hasonlóképpen a horvátoknak is fontos volt visszaszerezni irányításukat az adriai kikötőkhöz vezető útvonalak fölött, amelyeket a szerb kisebbség tagjai vágtak el, amint behatoltak Krajina tartományba). A boszniai háború korai szakaszaiban, 1992-ben a szerb erök megkaparintották Bosznia több mint kétharmadát, lemészárolva a muzulmán lakosságot, akiket az elfoglait városokból és falvakból ủztek el, vagy nehéz helyzetben maradtak a beékelt, ostromlott városi területeken, mint például a balvégzetü Srebrenica, Gorazde és Szarajevó. A harcok során átírták az etnikai térképet, a szerb támadások eltávolították a muzulmán lakosság nagy részét Bosznia keleti feléből úgy, hogy Srebrenica és Zepa városok lakosságát kilakoltatták vagy kiirtották, amikor ezek a városok elestek 1995 júliusában, annak ellenére, hogy a muzulmánok 1992-ben még többséget alkottak Kelet-Bosznia városaiban. 1995 augusztusában a régen letelepedett szerb lakosságot egy erōs horvát offenzíva révén telepítették ki Krajina tartományból, majd egy következő offenzíva elủzte a 
szerbeket Bosznia nyugati részéröl ${ }^{15}$, Drvar és Jalce városok felé. Ám amikor elnéptelenítették és elfoglalták a területet, a szerb, horvát és muzulmán gyöztesek rájöttek, hogy hiányzik a lakosság, akivel be lehetne ezeket a területeket népesíteni.

A politikai földrajzi problémák nemzetközi szinten is megnyilvánultak, amikor Németország túl korán ismerte el Horvátországot, a náci bábállam emléke és az usztasák által elkövetett atrocitások képei elevenedtek fel. Az ENSZ hónapokig tartó habozása után NATO légierő avatkozott be, hogy megakadályozza a Szarajevót bekerítö szerb tüzérség bombázását, valamint azért, hogy megmutassa azon szándékát, hogy megvédi a civil lakosságot. Az orosz nacionalisták és hivatalos személyek a hidegháború újraindításával fenyegetőztek azon politika részeként, mely a régóta fennálló hagyományt tükrözi, miszerint Oroszország támogatja Szerbiát, általában az orosz geopolitikai stratégia eszközeként. A rég esedékes NATO hadmüveletet megelözően a muzulmán világ viszolygással figyelte a boszniai muzulmán lakosság legyilkolását és etnikai tisztogatását, amely nem sokkal azután történt, hogy a NATO erös hadmủveletet indított Kuvait felszabadítására. Azt a következtetést, miszerint a nyugati politikusok többet törődtek az olcsó kőolajtartalékokkal, mint a muzulmán életekkel, nehéz volt figyelmen kívül hagyni.

A fenti adatokból kitünik, hogy a huntingtoni civilizációs körök ${ }^{16}$ közül három is megtalálható a térségben: az ortodox közel fele arányban, a nyugati egyharmaddal és az iszlám egyötöddel (1. ábra). Ez a tény - többek között - a következök miatt válhatott az államszövetség szétesésének, $s$ azon túl fegyveres konfliktussá fajulásának okává:

1) Az etnikai-vallási megosztottság régiónként különbözö fokban érvényesült (pl. homogén Szlovénia, heterogén Bosznia-Hercegovina).

2) A nemzetiségek a területekből nem lélekszám-arányuknak megfelelö hányadban részesülttek ( $p l$. a boszniai muszlinok városlakók, míg a kevésbé urbanizált szerbek és horvátok a rurális térségben területileg jobban szétszóródtak).

3) Több helyen az etnikai kevertség olyan nagyfokú volt, hogy összefüggö nemzetiségi területek nem voltak kijelölhetök.

A nyugát-európai geopolitikai tárgyú munkák kategóriáit figyelembe véve megállapitható, hogy az ún. „univerzális” és „kulturális” identitáshoz való hüség e térségben megelözte a „nemzeti” és „patrióta” kötődést, holott ideális esetben e négy, hierarchikusan egymásra épülö (patrióta, nemzeti, kulturális, illetve univerzális), „plurális" identitáshoz való hüségnek egyưtt kellene érvényesülnie (Petschen 1994). ${ }^{17}$

A fenti modell is alátámasztja a huntingtoni teóriát arról, hogy a regionális (de Rougement-nál és Petschennél: patrióta) és nemzeti kötődést felülmúlja a kulturális és az univerzális. Ez utóbbi minḍig a vallási kötődést jelenti, vagyis az univerzális kötődés domináns - igaz, így e térségben meg is cáfoltuk a Petschen (1994) által kívánatosnak tartott régiómodellt. ${ }^{18}$ Azért pedig, hogy a fentiek következtében a nemzetek békés egyuittélése a jövőben szinte lehetetlenné vált, nagymértékben felelőssé tehetỏ az itt kibontakozott törésvonal-háború. Az ilyen típusú háborúkra 
jellemzö, hogy sokáig tartanak, intenzitásuk váltakozó és sok áldozattal (emberveszteség, menekültek, anyagi kár) járnak. ${ }^{19}$

Amikor egy adott fegyveres konfliktust - jelen esetben a délszláv válságot - földrajzi szempontból vizsgálunk, sorra kell vennünk az események objektív és szubjektív fơldrajzi színterének sajátságait, szerepét. Az objektiv földrajzi tér fogalomkörébe a konkrét tér, és annak természetföldrajzi adottságai tartoznak, a gazdaságföldrajzi jellemzőivel együtt (mint a bányászat, ipar, infrastruktúra térszerkezeti elemei). A szubjektív földrajzi tér azt a gondolati térképzetet jelenti, ahogyan az ember és a közösségek tudatában az objektív földrajzi tér megjelenik. Ez utóbbinál Fliedner (1992) és Muir (1997) - a magyar geográfiai irodalomban eleddig nem alkalmazott - elméleteit használom a konkrét helyzetre vonatkoztatva.

Egy politikai földrajzi reflexió nem kerülheti meg annak a kérdésnek a tárgyalását, hogy a volt Jugoszlávia hogyan jelent meg a nemzetiségek és az uralkodó nemzeti elitek politikai gondolkodásában. Jugoszláviában ugyanis a különbözö nemzetiségek más síkon gondolkodtak ugyanarról a térröl. Valójában arról van szó, hogy eltérö módon definiálják a teret: konkrét területeket követelnek maguknak általános ideológiai alapon. Fliedner (1992) térmeghatározása hüen tükrözi a nyugati szakirodalomban már meghonosodott, Magyarországon kevésbé alkalmazott felfogást (Nemes Nagy 1998). ${ }^{20}$ Eszerint a tér egymással összekapcsolódó elemek rendje, amely centrum-periféria alapon épül fel, s olyan, anyag- és energiaáramlások funkcionálisan differenciált, idöben, térben és hierarchikusan megalkotott rendszere, amely magát állandóan újraformázza (ez tulajdonképpen az einsteini téridỏ kontinuitás történelmi, földrajzi leképezése). Számunkra a lényeges momentum itt az, hogy véleménye szerint a teret korábban az idő mellett létező kanti ortogonális térként kezelték. A délszláv állam széthullásának teljes megértése azonban csak úgy lehetséges, ha az időt és a teret nem külön fogalomként kezeljük, hiszen - mint az elöbbiekböl is kiderül - adott térröl csak adott időben van értelme beszélni, mivel a tér önmagát folyvást alakítja. Muirnál (1997) az idő és a tér egymástól elválaszthatatlan dimenziót alkot: az Időteret. Idô és tér a legelemibb paraméterei létezésünknek. Ezeket a fogalmakat életünk korai szakaszában megtanítják nekünk, mindannyian folyamatosan használjuk, tudjuk, mit jelentenek. Sôt tudjuk, hogy az idö és a tér a valóságnak két meglehetősen különböző dimenziója, bár általában egyformán fontosnak tekintjük öket. Tudjuk, objektív valóságok, nem tölünk függenek, és nem tudjuk öket jelentösen befolyásolni. Minden nagyobb politikai szervezet lényeges szükséglete a rend. Az idö rendje szabályoz minden közös emberi cselekvést. Állíthatjuk, hogy minden hatalom legföbb attribútuma az elrendezett idő. Ha egy épp létrejött hatalom meg akar maradni, neki kell látni, hogy újjárendezze az időt. Úgy, mintha vele kezdődne el az, ami még fontosabb, hogy mint új hatalom biztosítani akarja magát az elmúlás ellen magában az időben. A mindenkori hatalom a maga képére szeretné formálni az időstruktúrát, megpróbálja ezen keresztül ellenőrizhetöbbé tenni a társadalmat. Azt, hogy mekkorának ítéli önmagát valamely hatalom, az az időigényén ismerszik meg. Hitlernek például Ezeréves Birodalom kellett. Természetesen, mint a szövegkörnyezetböl is kiderül, gyakoribb, hogy több 
időstruktúra létezik egy adott államon és társadalmon belül (Canetti 1991). Úgy hiszem, hogy az Idötér fogalommá testesedésének döntő hatása lehet közös társadalmi jövőnkre nézve, és ezért fontos, hogy óvatos, megfontolt vizsgálatnak vessük alá a történelmet és e fogalom használatát.

Muir öt időteret kategorizált, melyek használatban vannak a modern világban (epizodikus-geopolitikus Időtér, ciklikus-ideologikus Időtér, strukturális Időtér, örökkévaló Időtér és transzformációs Időtér). Epizodikus-geopolitikus Idôtéren azokat a kategóriákat érti, melyekkel a közvetlen történelmet írjuk le, pl. a napilapokban (,a FIDESZ párt nyert a választásokon”). A közvetlen történelem nem feltétlenül jelent folyamatban lévő történelmet. A Bastille eleste 1789. július 14-én szintén epizodikus-geopolitikus Időtér. A lényeg, hogy meghatározása rövidtávú mind idöben, mind térben, és az események a közvetlen szövegkörnyezetük által nekik tulajdonított jelentéshez kötödnek.

Ciklikus-ideologikus Idótéren azokat a kategóriákat érti, melyekkel közvetlen történelmet írunk le, mint pl. egy jelenkori cselekményt (ld. egy választást), annak eredményét régóta fennálló vallási ellentétekkel magyarázzuk, vagy azzal, hogy az adott államnak és polgárainak nehézségei vannak az elmúlt, mondhatni történelmi nagyságának megszüntével, és annak a következményeinek a felszámolásával, vagy más, hosszú időre visszanyúló tényezök hangsúlyozásával. Igényli annak a helyzetnek a meghatározását, mely az idő- és térbeli elhelyezkedés jelentésének értékeléséböl származik.

Strukturális Idótéren azokat a kategóriákat érti, melyekkel olyan jelenségeket írunk le, mint az úgynevezett „Nyugat emelkedése”, vagy megpróbáljuk megérteni Kelet-Ázsia látványos gazdasági fejlődésének eredetét a modern világrendszer müködése szerkezeti magyarázatának fényében. Itt a magyarázatok sokkal hosszabb távúak, és valójában meghatározásai annak a történelmi rendszernek, melyben élünk, és ennek tér- és időbeli korlátainak.

Örökkévaló Idôtéren pl. az „etnikai tisztogatás” magyarázatát érti, az úgynevezett etnikai csoportok alapvetö összeférhetetlenségét egymással, vagy azokat az agresszív ösztönöket, melyekkel az emberi lények rendelkeznek, illetve még az éghajlatnak a társadalmi viselkedésre gyakorolt hatását is. A meghatározó jellemző itt az idő és tér elemzéshez nem tartozása, időtlenségének és tértelenségének feltételezése.

Végezetül, transzformációs Idôtéren pontosan az ellenkező fajtájú elemzést érti, amely kihangsúlyozza az előfordulás kulönlegességét, kivételes minőségét és világunk valamennyi jelentős intézményére gyakorolt eröteljes hatását. A keresztény felfogás Krisztus földi eljöveteléröl egy ilyen magyarázat. Tudjuk az évet és helyet idézni, de számítanak ezek valamit? Vagy ha egy világibb példát nézünk: mezőgazdasági forradalomról beszélünk. Itt is idézhetnénk az évet és a helyet, bár csak körülbelül meghatározva öket, de megint csak: számítanak ezek? Ami számít, az a mélyreható átalakulás vagy szakadás, amelyröl azt hisszük, hogy megtörtént, és amely minden azután következőt befolyásolt. És mégis, bár az adott hely és idő nem számít abban az értelemben, hogy nem képezik részét a tényleges és közvetlen 
magyarázatnak, a transzformációs Időtérről azt állítják, hogy előfordul, amint azt látni fogjuk, a megfeleló időben és helyen, vagyis az egyetlen időben és helyen, ahol előfordulhat. Összefoglalóan elmondható, hogy a széthullásban jelentớs szerepet játszott az időről és a térről való eltérő gondolkodásmód, amely például oda vezetett, hogy minden etnikum a történelem folyamán valaha létezett legnagyobb elterjedési területét jelölte meg elérendő „élettérként”.

$\mathrm{Az}$ Időtér öt változatával kapcsolatban igazából az a fontos, hogy mindegyikük egy teljesen más elemzési szinttel és az idö és tér kulönböző meghatározásaival szolgálnak számunkra. Továbbá, e változatok egyetlen kifejezése sem egyértelmü és vitathatatlan. Bármilyen magyarázatot nyújtunk az öt variáció bármelyikével kapcsolatban, lesznek olyanok, akik azt mondják majd, hogy rosszul határozzuk meg az időt és a teret.

Néha a vita arról folyik, hogy melyik Időtér a legfontosabb. Vonatkoztassuk a vitát - mely érthetetlen mindazok számára, akik nem érintettek benne - Koszovóra. Koszovó (10 $\left.887 \mathrm{~km}^{2}\right)$ egy földrajzi körzet neve az 1945 utáni Jugoszláviában. Tito elnöksége alatt ez az övezet kủlönleges politikajogi helyzetben volt. Bár nem volt tagja a hat szövetségi köztársaságnak, autonóm régiónak kiáltották ki az egyik szövetségi köztársaságon, Szerbián belül. Szerbia egyoldalúan visszavonta Koszovó autonóm státuszát. Koszovó lakosságának nagy többsége albán (2. ábra).

\section{2. ÁBRA}

Koszovó lakosságának etnikai megoszlása 1961-ben és 1991-ben

(Population of by Ethnic Groups in Kosovo, in 1961 and 1991)

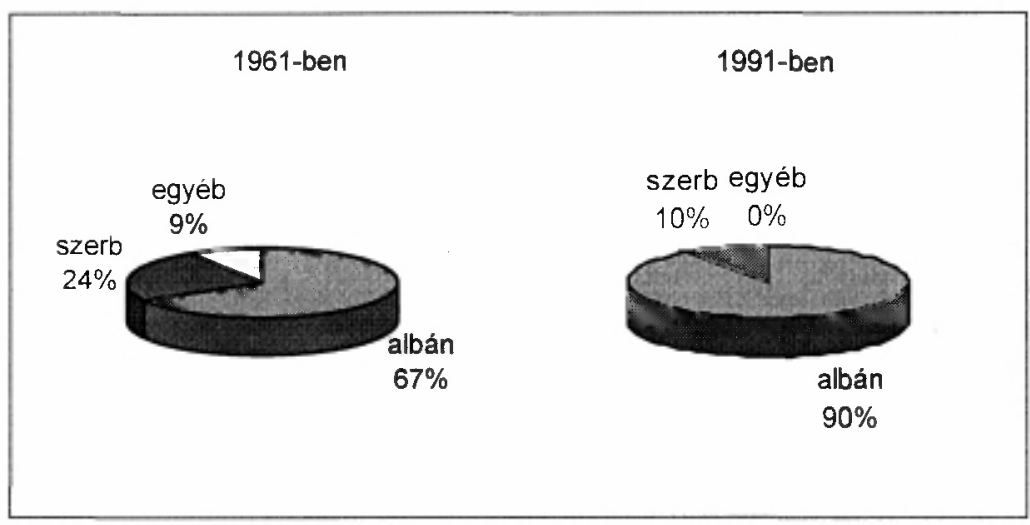

Forrás: Huntington 1998.

Számok alapján követelnek önrendelkezési jogot olyan területen, melynek hivatalos határait csak a XX. században jelölték meg. Az epizodikus-geopolitikus Időtér szempontjából érvelnek. A szerb kormány érvelése egészen más volt. Ỏk egy régóta létező entitás, a szerb nép nevében beszéltek. Azt mondják, hogy Koszovó a szerb nemzet történelmi bölcsője volt, mert 1389-ben a szerbek inkább a halált választották ahelyett, hogy megadják magukat az ottomán ellenségnek (akikhez az akkori albánok Koszovóban, akik ma muzulmánok, szellemileg asszimilálódtak). Az ér- 
velés szerint ez a csata keltette fel a szerb nemzeti ontudatot, és ezért elképzelhetetlen olyan szerb állam, amely nem tartalmazza Koszovót. Ezért - folytatták a szerbek - a jelenlegi népességi adatok és határok egyszerúen nem igazak: Koszovó erkőlcsileg Szerbia része volt a XIV. században tơrténtek miatt. Ez az érvélés strukturális idóteret használ. Egy ilyen vitát nem lehet intellektuálisan eldönteni. Egyik fél sem tudja demonstrálni igazát, amennyiben demonstráción azt értjük, hogy az érvelésúket valamilyen komoly bizonyitékkal alátámasztják. Ez egy politikai nézeteltérés, amelyben az Időtér koordinátái egyszerủen a felek eszközei. A kérdést csak politikailag lehet eldönteni. A szerbek figyelmen kívill hagyják azt a tényt, hogy az albánok részérỏl a nemzetiségiek aránya több mint 90\%-os (2. ábra), s ez a terület Európa legmagasabb szilletési rátajával bír.

Az eltérő gondolkodás áthidalhatatlan akadályokat gơrdít a két fél diskurzusmódozatai kőzé, ezért mondhatjuk, kizárólag politikai dőntés döntheti el a vitát és a két nép sorsát, de ezt a döntést, ha tetszik nekik, ha nem, nagyhatalmaknak ${ }^{21}$ kell meghozniuk. Ez pedig nehéz, hiszen Európa jelenlegi döntésmechanizmusa lassú (emlékezzünk a boszniai válságra). Hiszen volt idó, mikor az Egyesült Államok Európára bízta a döntést - a prágai nyilatkozattal egyidőben, illetve az azutáni idószakra gondolok -, másrészt nem hagyható figyelmen kívül az ellentétes orosz álláspont. Ez a nagyhatalmi döntés elérkezett, hiszen 1999. március 23-án elkezdőđött a belgrádi vezetés megbüntetése, de a veszély óriási, mert Koszovóban elkezdődőtt az etnikai tisztogatás. A vezető nyugati politikusoknak Dodonai döntést kell hozni, hiszen Koszovó függetlensége Macedóniảra nehezülne politikai destabilizáció formájában, ugyanis az ott élö 700 ezer albán egy tơmbben található, mely a lakosság 1,9 milliós nagysága mellett meghatározó részt képvisel. Ha a skopjei vezetés válságba kerủl - márpedig az albánok leválása esetén az állam múködésképtelen lenne -, mint a dominó terjedne tova a válság: Albániára, Bulgáriára és Görögországra. Másik oldalrỏl hivatkozási alap lehetne a boszniai szerb állam kiválására és Szerbiához való csatlakozásra, illetve a boszniai horvátok kiválására és Horvátországhoz való csatlakozásra. Arról nem is szólva, hogy „Kis-Jugoszlávia” (Szerbia) egy ilyen megoldásba semmiként nem egyezne bele, (itt nem a vezetésre gondolok, hanem magára a népre, mint egészre), mert identitásukban, önmeghatározásukban fontos helyet foglal el, sokkal fontosabbat, mint Bosznia. Két lehetốség van: egy széleskơrủ autonómia, de a jelenlegi államhatárokkal, vagy Koszovó politikai felosztása, aminek egyik eszköze a lakosság elūzése a tartomány északi és keleti feléböl. E területre energetikai okokból is szuksége van a szerbeknek, mert itt található az a hőerőmü központ, mely Szerbia jelentős részét ellátja, és politikailag eladható, hogy Koszovó egy részét megtartotta a vezetés. Sajnos az etnikai tisztogatás megállitására szárazfơldi erők bevetésére lenne szükség, de ettől a Fehér Ház óvakodik, mert a Szomáliában meghalt kétszáz amerikai katona emléke riasztó, hiszen az amerikai halottak nehezen ,eladhatóak” az amerikai kőzvéleménynek.

Maga a térség politikai földrajzi vizsgálata az érdeklődés középpontjába kerullt, és hiszek a gondolkodás montázs jellegében, az összkép megváltozásához sokszor elég egy apró elem kicserélése - ez akaratlanul bekövetkezhet egy párbeszéd „folyam" 
esetén - ahhoz, hogy az összkép prizmája már másképp bontsa meg világunk fényét. Talán ezért érdemes újra és újra a környezetünk problémáit megtárgyalni, megvizsgálni, mert maga a diskurzus az adott dologról fontosabb lehet, mint a megalkotott vélemények tömkelege. Délkelet-Európa államainak többségében nagy számban élnek etnikai kisebbségek, közülük sokan „megfertőzve” a határproblémák örökségével. Mindannyiunknak félnünk kell a ,jugoszláv vírus" terjedésétől. Ki gondolta volna egy évtizeddel ezelött, hogy háború fog kitörni itt, Európa köldökének közvetlen közelében.

\section{Jegyzetek}

1 A szerzỏ a kéziratot 1999 áprilisában adta le. A tanulmány tárgyában azóta is számos, közismert esemény tơrtént, melyek természetszerúleg nem szerepelhetnek a szövegben (szerk.).

A tanulmány megírását a Pro Renovanda Cultura Hungariae „Tơrténelem-Fơldrajz" Szakalapitvány és a Tempus program valamint a Kereskedelmi Bank Universitas Alapítvány támogatása tette lehetóvé.

${ }^{2}$ A politikai megfontolások mindig jelen voltak a foldrajztudományon belul, de az I. és a II. világháborút kővetően felerősődtek a politikai megkőzelitések. Ennek kővetkeztében részben maga a foldrajztudomány nemzeti célokat szolgáló területté vált.

${ }^{3}$ Ennek okai a vágyképekben vannak, amit mondhatunk ideológiának és utópiának, ettơl még könnyen meglovagolható, és veszélyforrásként fognak jelentkezni a jövőben (Mannheim 1996). Az emberi vágykivetítések formálódásukban megragadható elveknek engedelmeskednek, $s$ az ember bizonyos tơrténelmi korokban inkább idó-képekbe, máskor pedig inkább tér-képekbe vetíti vágyteljesuléseit (Doren 1927).

4 Az Egyesult Királyságban, ahol nincs alkotmány, a helyzet még bonyolultabb; azt mondják, hogy a szuverenitás ósszekapcsolódott a parlamentáris királysággal - mely olyan helyzet, amit nem valószínủ, hogy százból egy brit állampolgár is megért.

"E gondolatról az első írásokat Carl Jung (1995) tollából olvashatjuk „A Fôld és lélek” c. munkájában. Jelenleg egy, még magyarul fel nem fedezett sajátos tudományterulet, a geopszichológia foglalkozik vele.

" A szerb egység jelképe, hiszen nemzeti összefogás valósult meg a törők veszedelem ellen. Óriási vereséget szenvedtek, de a ,gonosz" Murád szultánt sikerult megölni, tóbbek közőtt ezért is vált ez a csata az ellenállás szimbólumává.

${ }^{7}$ Bowman neve az elsó világháború alatt az amerikai háború utáni rekonstrukciós elökészuletekkel, az európai nemzeti határok újrahúzásával kapcsolatban vált elismertté. Az Amerikai Főldrajzi Társaság (AGS) igazgatója, és mint vállalkozó de facto az Információs Iroda igazgatója lett, aminek feladata volt a sok kơtetnyi foldrajzi és térképészeti adat valamint forrás ósszeállitása, amelyet Woodrow Wilson elnők használt az 1919-es Párizsi Békekonferencián (Shotwell 1937; Gelfand I963). Wilson kinevezte Bowmant az USA párizsi delegációjának Teruleti Specialistáinak vezetőjévé, az ő irányítása alatt készitett térképeket a konferencián számos teruleti bizottság használta.

${ }^{8}$ A számításokat Juhász (I997, 132 o.), Toldi $(1994,17$ o.), Kocsis (1993, 14 o.) nyomán végeztem.

'A macedón nemzeti identitástudat kialakitását Belgrád mindig hatékonyan támogatta, elejét véve ezzel egy esetleges, Bulgáriához való integrálódási szándéknak (Romsics 1998). Van, aki osztja ezt a nézetet (Juhász 1997), máshol arra találunk utalást, hogy a crna gorai, muzulmán, macedón nemzet a második világháborí elott is létezett (Kocsis 1993).

${ }^{10}$ Találó J. V. Sztálin mondása: „A nyelv olyan dialektus, amelynek van hadserege”.

1 Meglepó módon Tơrökország lakosságának kb. 5\%-a bosnyák eredetü, ôseik két nagy hullámban 1878-ban és 1908-ban vándoroltak jelenlegi élóhelyukre.

12 Die Ethnostruktur der Lánder Sudosteurufgrund der beiden letzten Volkszahlungen im Zeitraum I977-1992. (Sudosteuropa, I993. 1. sz. 78-80.) nyomán. A magyarság tekintélyes része református, ezen kívul egyes százezresnél kisebb lélekszámú kisebbségeket nem vettem számításba elhanyagolható súlyuk miatt (pl. evangélikus szlovákok).

${ }^{13}$ Koszovó terulete volt például a kózponti terulete Dusán (1331-55) szerb államának, aki I346-ban Skopjéban (ma Macedónia székhelye) cárrá koronáztatta magát. Ebben az idóben a jelenlegi nyugatkoszovói Peđ városa volt a metropolita székhely. Ezzel megmagyarázható, hogy e kb. kilencezer lakosú várost miért lakoltatta ki az elsók közőtt a szerb karhatalom. 
${ }^{14}$ Nemrég jelent meg német nyelven is Richard Holbrooke visszaemlékezése „Meine Mission (Vom Krieg zum Frieden in Bosnien" (1998) címmel, mely sajátos amerikai olvasatát nyújtja az ott tơrténteknek.

15 A rendelkezésre álló adatok nem egyértelmúek. Kb. 600 ezer szerb menekült telepedett le KisJugoszláviában, sajnos tơbb mint 300 ezer a valamikori Vajdaság teruletén, ami természetszerüleg felborította a térség nemzetiségi palettáját. Ha az ott élö magyarok számát 350 ezerben állapítjuk meg, melyek kơzül a besorozás elöl 35 ezren elmenekültek (pár ezren azóta visszakőltơztek), akkkor láthatjuk a kedvezőtlen tendenciát, külőnősen úgy, hogy az elmenekült fiatalok után demográfiai ür maradt a helyi magyar társadalom korfa szerkezetében, ami a jövőben várhatóan csak súlyosbodni fog (gondolok a meg nem született gyermekekre).

${ }^{16}$ A Foreign Affairs 1993 nyári számában „The Clash of Civilisations?" jelent meg e felosztás: nyugati, ortodox, iszlám kultúrkör, konfucianizmus, buddhizmus, Latin-Amerika, Fekete-Afrika, Hinduizmus, Shintoizmus.

${ }^{17}$ A szerzỏ Denis de Rougement kategorizálását idézi, aki viszont svájci lévén, bizonyára nem volt jól tájékozott a balkáni helyzetet illetően.

${ }^{i}$ Petschen a nemzetközi egyưttélés három modelljérỏl értekezik, $\mathrm{s}$ az exjugoszláv térségben az ő kategóriái szerint az idejétmúlt tradicionális-államközpontú modell maradt uralkodó.

${ }^{19}$ Huntington (1998) kiszámolta, hogy átlag hatszor hosszabbak az államkőzi konfliktusoknál. Az utóbbi évtizedben a Fưlöp-szigeteken 50, Srí Lankán 50-100, Kasmírban 20, Szudánban 500-1500, Tadzsikisztánban 100, Tibetben 100, Kelet-Timorban 200, Csecsenfoldön 30-50, Horvatországban 50, Bosznia-Hercegovinában 200 ezer halálos áldozatot kóveteltek.

${ }^{20}$ Az újabb hazai térkutatás képviselöi, mint Nemes Nagy József (1998) - hivatkozva Fodor (1985), Sántha (1986), Vidor (1994), Gergely (1996) munkáira - számos tértípusról beszél.

${ }^{21}$ A menekultkérdés is egyfajta nyomást gyakorló fájó pont lehet. Ebben a kérdésben Németország a legérintettebb, hiszen jelenleg 400 ezer albán él ott, ebböl 150 ezerre teszik a koszovói származásút, valamint havonta érkezik még körülbelül 4 ezer. Természetesen egy kiterjedt polgárháború esetén mely felé mutałnak a tények - ennél jóval magasabb számok kerekednének ki. A másik fontos érintett Olaszország, aki jelentős szerepet vállalt az Albán-válság idején, és szintén nagy számban élnek ott menekültek. Nem szabad figyelmen kívül hagyni Olaszország vágyát, jól körvonalazható szándékát e térséget érintő feszulltségek rendezésében. Albánia gazdasági helyzete viszont nem teszi lehetővé 2-300 ezer menekült ellátását.

\section{Irodalom}

Canetti, E. (1991) Tömeg és hatalom. Budapest, Európa Könyvkiadó.

Conner, W. (1978) A Nation Is a Nation, Is a State, Is an Ethnic Group, Is a... - Ethnic and Racial Studies. 1. 377-400. o.

Conner, W. (1993) Beyond Reason: The Nature of the Ethnonational Bond. - Ethnic and Racial Studies. 16. 373-389. o.

Doren, A (1927) Wunschträume und Wunschzeiten. Leipzig.

Erikson, E.H. (1975) Life History and the Historical Moment. Norton Publishers.

Falk, R. (1992) Explorations at the Edge of Time. Philadelphia, Temple Press.

Fodor L.-né (1985) A társadalmi tér elméleti kérdései a térelmélettel foglalkozó tudományok megállapitásainak tükrében. Kandidátusi értekezés, Budapest (kézirat).

Frank, A.G. (1975) Independent Development. London, Methuen.

Frankel, J. (1964) International Relations. London, Oxford Uni. Press.

Fliedner, D. (1992) Antropogeographie, paradigmenwechsel, kulturelle Evolution. - Geographische Zeitschrift. 1. 1-20. o.

Fukuyama, F. (1994) A történelem vége. Budapest, Európa Könyvkiadó.

Fukuyama, F. (1997) Bizalom. Budapest, Európa Könyvkiadó.

Gelfand, L.E. (1963) The Inquiry: American Preparations for Peace, 1917-1919. New Haven, Yale Uni. Press.

Gergely A. (1996) Identitás és etnoregionalitás: a kisebbségi identitás történeti és regionális összefüggései Nyugaton és Kelet-Közép-Európában. Budapest, MTA Politikai Tudományok Intézete.

Hobsbawm, E. (1998) A nacionalizmus kétszáz éve. Budapest, Maecénás Kiadó.

Huntington, S.P. (1993) The Clash of Civilization. - Foreign Affairs. 3. 22-49. o.

Huntington, S.P. (1998) A civilizációk összecsapása és a világrend átalakulása. Budapest, Európa Könyvkiadó. 
Juhász J. (1997) A délszláv háborík. Budapest, Napvilág Kiadó.

Jung, C.G. (1995) Föld és lélek. Budapest, Kossuth Könyvkiado.

Katona P. (1999) Jugoszlávia felbomlásának geopolitikai vonatkozásai. Szakdolgozat, Debrecen, KLTE, Társadalomfoldrajzi és Teruletfejlesztési Tanszék.

Kocsis K. (1993) Az etnikai konfliktusok történeti-földrajzi háttere a volt Jugoszlåvia területén. Budapest, Teleki László Alapitvány.

Licht, S. (1993) After Yugoslavia. Altered States.- Bennis, P.-Moushabeck (ed.) New York, Olive Branch.

Mann, M. (1984) The Autonomous Power of the State: Its Origins Mechanisms and Results. - Archives Européennes de Sociologie. 25. 185-213. o.

Mannheim K. (1996) Ideológia és utópia. Budapest, Atlantisz.

Muir, R. (1997) Political Geography. London, Macmillan Press LTD.

Nemes Nagy J. (1998) A tér a társadalomkutatásban. Bevezetés a regionális tudományba. Budapest, Hilscher Rezső Szociálpolitikai Egyesület.

Oppenheimer, F. (1912) Az állam. Budapest, Révai-kiadás.

Petschen, S. (1994) Nationalismus und das Europa der Regionen. - Welt Trends. 4. Geopolitik: ein altes Konzept wird neu befrag. 119-129. 0.

Romsics I. (1998) Nemzet, nemzetiség és állam Kelet-Közép és Délkelet-Európában a 19. és 20. században. Budapest, Napvilág Kiadó.

Sántha J. (1986) Telepuilés és társadalom. Budapest, Baranya Megyei Épitto Vállalat.

Shotwell, J.T. (1937) At the Paris peace Conference. New York, Macmillan.

Toldi F. (1994) A jugoszláv állam története. Budapest, Közgazdasági és Jogi Kiadó.

Vidor F. (1984) Az épitészeten innen és túl. Budapest, Gyorsjelentés Kiadó.

Walker, R.B.J. (1990) Security, Sovereignty and the Challenge of World Politics. - Alternatives 15. 3-27. o.

Wilkinson, H.R. (1951) Maps and Politics: A Rewiew of the Ethnographic Cartography of Macedonia. Liverpool, Uni. Press. 